\title{
Deep Autotrophic Soil Respiration in Shrubland and Woodland Ecosystems in Central New Mexico
}

\author{
D. O. Breecker, ${ }^{1 *}$ L. D. McFadden, ${ }^{2}$ Z. D. Sharp, ${ }^{2}$ M. Martinez, ${ }^{1}$ \\ and M. E. Litvak ${ }^{3}$
}

\begin{abstract}
${ }^{1}$ Department of Geological Sciences, The University of Texas at Austin, Austin, Texas 78712, USA; ${ }^{2}$ Department of Earth and Planetary Sciences, The University of New Mexico, Albuquerque, New Mexico 87131, USA; ${ }^{3}$ Department of Biology, The University of New Mexico, Albuquerque, New Mexico 87131, USA
\end{abstract}

\begin{abstract}
Quantifying the controls on soil respiration is important for understanding ecosystem physiology and for predicting the response of soil carbon reservoirs to climate change. The majority of soil respiration is typically considered to occur in the top $20-30 \mathrm{~cm}$ of soils. In desert soils, where organic matter concentrations tend to be low and plants are deeply rooted, deeper respiration might be expected. However, little is known about the depth distribution of respiration in dryland soils. Here we show that the average depth of soil respiration between pulse precipitation events is almost always greater than $20 \mathrm{~cm}$ and is frequently greater than $50 \mathrm{~cm}$ in two central New Mexico desert shrublands. The average depth of soil respiration in a piñon-juniper woodland was shallower, between 5 and $40 \mathrm{~cm}$. In the shrublands, $8 \%$ seasonal variations in the carbon isotope composition of soilrespired $\mathrm{CO}_{2}\left(\delta^{13} \mathrm{C}_{\mathrm{r} \text {-soil }}\right)$ that correlate with vapor
\end{abstract}

pressure deficit support root/rhizosphere respiration as the dominant source of soil $\mathrm{CO}_{2}$. Such deep autotrophic respiration indicates that shrubs preferentially allocate photosynthate to deep roots when conditions near the surface are unfavorable. Therefore, respiration rates in these soils are not necessarily correlated with root biomass. The $\delta^{13}$ $\mathrm{C}_{\mathrm{r} \text {-soil }}$ values provide no evidence for $\mathrm{CO}_{2}$ evolved from soil inorganic carbon. Our results also suggest that organic carbon cycling is rapid and efficient in these soils and that the $\delta^{13} \mathrm{C}$ value of $\mathrm{CO}_{2}$ respired from soils in much of the southwestern US, and perhaps in other semiarid regions, varies seasonally by at least $4 \%$.

Key words: soil respiration; soil depth; desert; carbon isotopes; vapor pressure deficit; New Mexico; autotrophic.
Received 16 April 2011; accepted 21 September 2011; published online 19 October 2011

Author Contributions: D. Breecker: conceived and designed study, selected study locations, performed research, interpreted results, and wrote article; Z. Sharp: conceived study, helped to write the article, and oversaw stable isotope analyses; L. McFadden: conceived study, helped select study location, and helped to write the article; M. Litvak: interpreted results and helped to write the article; M. Martinez: coded the numerical $\mathrm{CO}_{2}$ model and performed research using the model.

*Corresponding author; e-mail: breecker@jsg.utexas.edu

\section{INTRODUCTION}

Carbon dioxide $\left(\mathrm{CO}_{2}\right)$ emitted from soils to the atmosphere constitutes one of the largest fluxes of carbon to the atmosphere (Raich and Schlesinger 1992). Small but sustained perturbations in the flux of soil-respired carbon could, therefore, drastically alter the $\mathrm{CO}_{2}$ concentration of Earth's atmosphere. Debate surrounding the sensitivity of soil carbon stocks to global change (for example, 
Davidson and Janssens 2006) must be resolved to constrain future carbon budgets and predict future climate conditions. Scaling up from individual sites to the global scale will require a mechanistic understanding of soil respiration, which we help to develop by studying the origin of $\mathrm{CO}_{2}$ in central New Mexican soils.

The $\mathrm{CO}_{2}$ flux from dryland (arid and semiarid region) soils, although relatively small on a unit area basis, constitutes a significant portion of the global carbon cycle because drylands cover approximately $40 \%$ of Earth's land surface (Taylor and Lloyd 1992; Shen and others 2008). In dryland soils, uncertainty exists in relative contribution to total soil $\mathrm{CO}_{2}$ efflux from root/rhizosphere respiration (autotrophic respiration), from decomposition of soil organic matter (heterotrophic respiration) and from abiotic sources (for example, calcium carbonate in soils). This uncertainty masks the processes important in the transfer of $\mathrm{CO}_{2}$ from soils to the atmosphere. Investigating the sources of $\mathrm{CO}_{2}$ emitted from dryland soils is therefore important for quantifying the global carbon cycle and, on a smaller scale, for understanding ecosystem carbon exchange in these biomes. In drylands, pulses of biological activity caused by precipitation events punctuate background "between-pulse" levels of biological activity (Noy-Meir 1973). We studied the origin (depth and source) of the "between-pulse" soil-respired $\mathrm{CO}_{2}$ (with the intention to investigate pulse events in the future) to help develop a mechanistic understanding of dryland soil respiration.

\section{BACKGROUND}

Biological $\mathrm{CO}_{2}$ is produced in soils by respiration in the rhizosphere (by plant roots and by associated heterotrophic microorganisms) and by the nonrhizosphere microbial oxidation of organic matter (decomposition). The accumulation of $\mathrm{CO}_{2}$ in soil pore spaces (soil $\mathrm{CO}_{2}$ ) causes the development of soil-atmosphere concentration gradients, which result in net $\mathrm{CO}_{2}$ diffusion into the atmosphere, a flux typically termed soil-respired $\mathrm{CO}_{2}$. The flux of $\mathrm{CO}_{2}$ from soils is known to be sensitive to soil moisture and temperature, among other variables, but a mechanistic understanding useful for modeling, extrapolation and prediction is lacking.

A mechanistic understanding of soil respiration must involve spatial distribution. For instance, soil respiration rates at discrete depths should ideally be compared with soil temperatures, soil moisture, and so on at those depths. However, the number of studies in which the depth distribution of soil respiration has been investigated is very small compared with the number of studies in which the flux across the soil-atmosphere interface was the only $\mathrm{CO}_{2}$ measurement made. It is typically assumed that soil respiration primarily occurs in the top $20-30 \mathrm{~cm}$ of soils and that soil respiration rates below this depth are negligibly small. The concentration of soil organic matter is highest in the near surface soil $\mathrm{O}$ and A horizons and decreases exponentially with increasing depth in most soils. Therefore, the assumption that soil respiration is primarily confined to the top several decimeters is probably true for most temperate forest and prairie soils, as suggested by previous studies of soil $\mathrm{CO}_{2}$ profiles (de Jong and Schappert 1972; Dörr and Münnich 1990; Drewitt and others 2005; Hashimoto and others 2007). However, considerable soil respiration below $20 \mathrm{~cm}$ soil depth has been documented in some soils (Hirsch and others 2002; Davidson and others 2006) and average depths of soil respiration up to $40 \mathrm{~cm}$ have been observed during droughts (Fierer and others 2005; Hashimoto and others 2007).

The depth distribution of roots is also an important consideration for understanding soil respiration, especially in soils with low organic matter contents such as desert soils. Desert shrub roots are known to extend to depths below $5 \mathrm{~m}$ (Gile and others 1998) even in soils with petrocalcic horizons (Gibbens and Lenz 2001). These deep roots are known to uptake P (Hartle and others 2006) but their contribution to soil respiration is poorly understood. The average depth of soil respiration varied between 5 and $40 \mathrm{~cm}$ in a sand dune with low soil organic matter content planted with a Pinus radiata tree (Cook and others 1998), but soil water was maintained at field capacity in this study and so natural variations were not observed. Naturally occurring depths of soil respiration in desert soils are essentially unknown, despite repeated documentation of such deep rooting systems. The fist objective of this study was to determine the depth of soil respiration in some central New Mexican woodland and shrublands.

A mechanistic understanding of soil respiration must also include an understanding of the relative contribution from different carbon sources to total $\mathrm{CO}_{2}$ efflux. The second objective of this study was to use variations in carbon isotope composition of $\mathrm{CO}_{2}$ produced in soils $\left(\delta^{13} \mathrm{C}_{\mathrm{r} \text {-soil }}\right)$ to identify the source of soil-respired $\mathrm{CO}_{2}$. Changes in the value of $\delta^{13} \mathrm{C}_{\mathrm{r} \text {-soil }}$ are controlled by multiple mechanisms, which can be divided into two broad categories.

The first category involves changes in the $\delta^{13} \mathrm{C}$ value of the substrate supplied to the roots of plants and available for respiration in the rhizosphere. For 
instance, changes in the magnitude of photosynthetic discrimination (against ${ }^{13} \mathrm{C}$ ) are thought to cause changes in the $\delta^{13} \mathrm{C}$ value of $\mathrm{CO}_{2}$ respired in the rhizosphere. Previous studies (Ekblad and Högberg 2001; McDowell and others 2004a) reported correlations between $\delta^{13} \mathrm{C}_{\mathrm{r} \text {-soil }}$ and vapor pressure deficit (vpd) (saturation vapor pressure-actual vapor pressure). Changes in vpd influence stomatal conductance, which influences the ratio of $p \mathrm{CO}_{2}$ inside leaves to $p \mathrm{CO}_{2}$ in the atmosphere, which in turn influences the discrimination against ${ }^{13} \mathrm{C}$ during photosynthesis and ultimately the isotopic composition of assimilated carbon. Higher relative humidity (that is, low vpd) results in increased stomatal conductance, which causes greater carbon isotope discrimination and hence lower $\delta^{13} \mathrm{C}$ values of photosynthate (Farquhar and others 1989). The $\delta^{13} \mathrm{C}_{\text {r-soil }}$ values measured by Ekblad and Högberg (2001) and by McDowell and others (2004a) correlate best with relative humidity or vpd several days prior to collection of $\mathrm{CO}_{2}$ emitted from the soil, suggesting that recently assimilated carbon is rapidly ( $1-4$ days) transported from leaves to the rhizosphere where it can then be respired. In addition to relative humidity, soil moisture might induce a stomatal response that influences $\delta^{13} \mathrm{C}_{\mathrm{r} \text {-soil }}$ (Fessenden and Ehleringer 2003) and $\delta^{13} \mathrm{C}_{\mathrm{r}}$ (ecosystem-respired $\mathrm{CO}_{2}$ ) (McDowell and others 2004b) values.

The second category of mechanisms that influence $\delta^{13} \mathrm{C}_{\mathrm{r} \text {-soil }}$ involves changes in the relative contributions of different sources of soil respiration. Steinmann and others (2004) suggested two potential soil processes that might explain the elevated $\delta^{13} \mathrm{C}_{\mathrm{r} \text {-soil }}$ values they observed during the dry, hot summer at their field site near Basel Switzerland. Their first potential explanation for high summer $\delta^{13} \mathrm{C}_{\mathrm{r} \text {-soil }}$ values was an increase in the ratio of rhizosphere to non-rhizosphere respiration. Rhizosphere respired $\mathrm{CO}_{2}$ under seasonally dry conditions should have a higher $\delta^{13} \mathrm{C}$ value than non-rhizosphere respired $\mathrm{CO}_{2}$ because the source substrate of the former, recent photosynthate, is assimilated with a smaller discrimination than is bulk soil organic matter, most of which was assimilated under more humid conditions. Steinmann and others' (2004) second explanation, also advocated by Flanagan and others (1999), was an increase in the relative contribution to soil respiration from deeper in the soil, where $\delta^{13} \mathrm{C}$ values of soil organic matter tend to be higher than they are near the surface (for example, Nadelhoffer and Fry 1988; Melillo and others 1989; Wynn and others 2005; Wynn and others 2006). Laboratory incubation of Alfisols from the Duke Forest Free Air $\mathrm{CO}_{2}$ Enrichment experiment showed that the $\delta^{13} \mathrm{C}$ value of respired $\mathrm{CO}_{2}$ is $2.2-3.5 \%$ higher at $4^{\circ} \mathrm{C}$ than

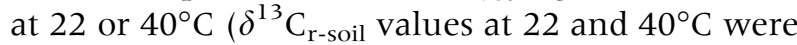
indistinguishable), due to changes in microbial community structure and a resulting change in the substrate being respired (Andrews and others 2000). In deciduous forest plots trenched to remove active roots, Moyes and others (2010) found that the $\delta^{13} \mathrm{C}$ value of soil-respired $\mathrm{CO}_{2}$ was $5 \%$ lower during the winter than during the summer. Substantial cooling is therefore thought to increase the $\delta^{13} \mathrm{C}$ value of heterotrophic $\mathrm{CO}_{2}$ in certain soils and decrease the $\delta^{13} \mathrm{C}$ value of heterotrophic $\mathrm{CO}_{2}$ in other soils.

In mixed $\mathrm{C}_{3}-\mathrm{C}_{4}$ ecosystems, variations in the relative proportion of $\mathrm{C}_{3}$ versus $\mathrm{C}_{4}$ rhizosphere respiration might cause large variations in $\delta^{13} \mathrm{C}_{\mathrm{r} \text {-soil }}$ values. The efficiency of $\mathrm{C}_{4}$ photosynthesis is known to increase in comparison with $\mathrm{C}_{3}$ photosynthesis as temperature increases (Ehleringer 1978; Ehleringer and others 1997) and temperature is therefore thought to control the seasonal transition from $\mathrm{C}_{3}$ to $\mathrm{C}_{4}$ dominated photosynthesis in prairie ecosystems (Kemp and Williams 1980; Ode and others 1980; Lai and others 2006). If photosynthesis drives rhizosphere respiration (Högberg and others 2001) then changes in the relative proportion of $\mathrm{C}_{3}$ versus $\mathrm{C}_{4}$ photosynthesis should result in changes in the relative proportion of $\mathrm{C}_{3}$ versus $\mathrm{C}_{4}$ rhizosphere respiration. Lai and others (2006) attributed the seasonal increase in the $\delta^{13} \mathrm{C}$ value of total ecosystem respiration in a tallgrass prairie to a relative increase in the contribution from $\mathrm{C}_{4}$ grasses, which in turn was explained by the decreasing light use efficiency of $\mathrm{C}_{3}$ plants with increasing temperature.

To help develop a mechanistic understanding of dryland soil respiration we tested two hypotheses concerning semiarid and arid regions where $\mathrm{O}$ horizons are absent, soil A horizons contain little organic matter and plants are deeply rooted: (1) respiration occurs throughout the top meter of soil rather than being confined to the top several decimeters, (2) in these desert soils with low organic matter contents, autotrophic respiration dominates the soil-atmosphere $\mathrm{CO}_{2}$ flux. We tested hypothesis 1 by measuring profiles of soil $\mathrm{CO}_{2}$ concentration in shrubland and woodland ecosystems in semi arid central New Mexico. We tested hypothesis 2 by measuring seasonal changes in the carbon isotope composition of soil-respired $\mathrm{CO}_{2}$.

\section{MeThodS}

\section{Study Sites}

The study was conducted on the Sevilleta National Wildlife Refuge (SNWR) in central New Mexico 
(Figure 1). New Mexico has a semiarid monsoon climate. Mean annual precipitation varies strongly with elevation. In low elevation shrublands and grasslands approximately $70 \%$ of annual precipitation occurs during July, August, and September, whereas in conifer woodlands approximately 50\% of annual precipitation occurs during these three summer months (Anderson-Teixeira and others 2011). We collected soil $\mathrm{CO}_{2}$ from three biomes that characterize much of New Mexico and the semiarid southwestern United States (1) Piñonjuniper woodland (PJ), (2) Great Basin shrubland (GBS), and (3) Chihuhuan Desert shrubland (CDS). One site in each of these biomes was chosen for this study (Figure 1); the same sites were used in Breecker and others (2009). The Chihuhuan Desert shrubland that we studied is nearly monospecific, dominated by the $\mathrm{C}_{3}$ shrub creosote bush (Larrea tridentata). All the sites were located on recently abandoned sandy channel alluvium. The soils at each site are probably late Holocene in age and have undergone only very weak pedogenesis. The soil at the piñon-juniper site has a $20 \mathrm{~cm}$ thick ochric (light-colored) A horizon but A horizons in the other soils are thin and very poorly developed. Weak $\mathrm{Ck}$ (minimal pedogenic alteration with the exception of soil-formed calcite coatings on the underside of clasts) horizons underlie the ochric A horizons in all the soils. There are no petrocalcic horizons in these soils unlike other areas on the SNWR. Vegetation at all four sites is a mixture of $C_{3}$ and $\mathrm{C}_{4}$ plant species.

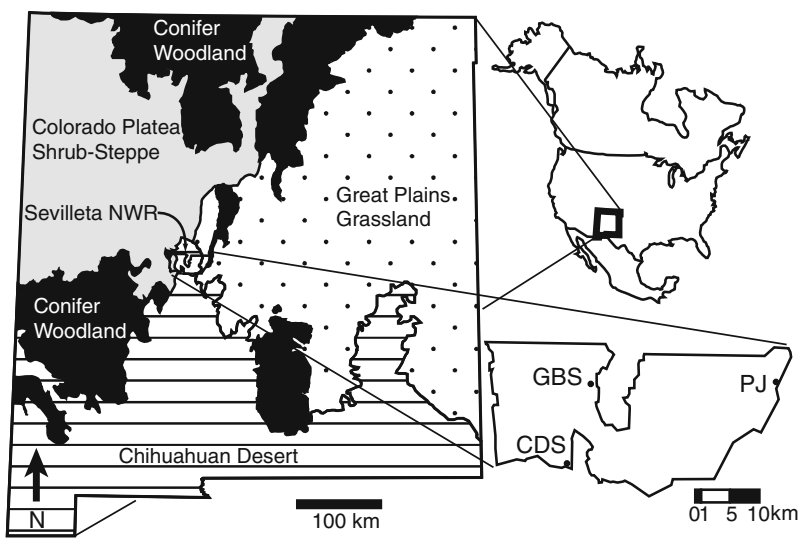

Figure 1. Study location map. The biomes studied are representative of much of the southwestern United States of America. The Great Basin shrubland (studied here) is similar, but not identical to the Colordao Plateau Shrub Steppe biome pictured on the map. PJ Piñon-Juniper Woodland; CDS Chihuahuan Desert Shrubland; GBS Great Basin Shrubland.

\section{Soil $\mathrm{CO}_{2}$ Collection and Analysis}

The sample collection and analytical methods are described in detail by Breecker and Sharp (2008). Nine or ten septum-capped soil gas wells constructed of $1 \mathrm{~m}$ lengths of $1 / 4^{\prime \prime}(6.35 \mathrm{~mm})$ O.D. stainless steel tubing, crimped shut at one end, were installed horizontally in the top meter of the soil at each site. Slits were created in the sidewall of the wells to allow gas entry. The volume of the soil gas wells was approximately $16 \mathrm{ml}$. Soil gas samples $(0.2-1.5 \mathrm{ml})$ were collected from the wells using a syringe approximately once per month beginning in September 2006 and continuing through May 2008. Most of the soil gas samples were collected at least 5 days after the last measurable precipitation event. With only a few exceptions (dates specified below), when precipitation did occur less than 5 days before collection, less than $1 \mathrm{~cm}$ of precipitation was recorded over the 5 days prior to soil gas collection. The soil gas samples measured in this study are representative of the pore space $\mathrm{CO}_{2}$ at the slits in the wells (a sub $\mathrm{cm}$ depth resolution). The natural $\mathrm{CO}_{2}$ gradient was not disturbed by monthly gas collection because the syringe samples consisted entirely of gas from the well itself, which had equilibrated with gas in the pore space immediately surrounding the well opening. The concentration and stable isotope composition of $\mathrm{CO}_{2}$ in the gas samples was determined in the stable isotope laboratory at the University of New Mexico using the automated technique described in Breecker and Sharp (2008). Carbon isotope compositions are reported here in the standard delta notation relative to VPDB calibrated to a $\delta^{13} \mathrm{C}$ value of NBS-19 $=2.02 \%$ (Hut 1987). During each sampling campaign, samples of atmospheric air were collected and soil temperature was measured at multiple depths using buried TC-PVC Omega ${ }^{\circledR}$ thermocouples and a handheld meter. The soil $\mathrm{CO}_{2}$ and temperature data used in this study were reported in a previous study (Breecker and others 2009). Air temperature and vapor pressure data (available from the Sevilleta Long Term Ecological Research project website: http://sev.lternet.edu) averaged over the daylight hours 2 weeks prior to each sampling campaign were used to calculate vpd.

\section{Soil $\mathrm{CO}_{2}$ Models}

Average depths of soil respiration $\left(z_{\text {avg }}\right)$ and soil respiration rates were determined by fitting $\mathrm{CO}_{2}$ profiles calculated using a numerical productiondiffusion model to measured soil $\mathrm{CO}_{2}$ profiles. 
A least squares minimization program was used to find best-fit values for $z_{\text {avg }}$. Fick's second law of diffusion can be expressed for soil $\mathrm{CO}_{2}$ as:

$$
\frac{\partial C}{\partial t}=D_{\mathrm{s}}(z) \frac{\partial^{2} C}{\partial z^{2}}+P(z)
$$

where $C$ is the $\mathrm{CO}_{2}$ concentration in soil pores, $t$ is time, $D_{\mathrm{s}}$ is the effective diffusion coefficient for $\mathrm{CO}_{2}$ in the soil, $z$ is depth and $P(z)$ is the depth dependent production rate of $\mathrm{CO}_{2}$. We solved equation (1) using a finite difference predictor-corrector method. We used the following equation to calculate $D_{\mathrm{s}}$ (Bird and others 1960; Moldrup and others 2000):

$$
D_{\mathrm{s}}=D_{\mathrm{air}} \frac{\theta_{\mathrm{a}}^{2.5}}{\theta_{\mathrm{t}}}\left(\frac{P_{0}}{P} \frac{T+273}{T_{0}+273}\right)^{1.823}
$$

where $D_{\text {air }}$ is the diffusion coefficient for $\mathrm{CO}_{2}$ in air, $\theta_{\mathrm{a}}$ is the free air porosity, $\theta_{\mathrm{t}}$ is the total porosity, $P_{0}$ is the air pressure at sea level, $P$ is the air pressure at the elevation of interest, $T_{0}$ is $25^{\circ} \mathrm{C}$, and $T$ is the soil temperature in ${ }^{\circ} \mathrm{C}$. We used measured soil temperatures at $40-60 \mathrm{~cm}$ for $T$ (reported in Breecker and others 2009) and the elevation of each site to calculate $P$. The average depth of respiration and vertical changes in free air porosity both control the curvature of soil $\mathrm{CO}_{2}$ concentration profiles. Deeper respiration and decreases in free air porosity with depth both result in less profile curvature when compared with shallower respiration and constant porosity with depth. We estimated the shallowest average depths of soil respiration (and the corresponding maximum soil respiration rates) that are consistent with our measured soil $\mathrm{CO}_{2}$ concentrations by considering a maximum vertical decrease in free air porosity. We assumed constant total porosity with depth, which is justified due to minimal pedogenesis (no B horizons) and the consistent texture (all sand) of these soils. We also assumed the maximum increase in water content with depth in the soils studied is equivalent to the maximum increase in water content with depth measured using time domain reflectometry at another site on the SNWR (Deep Well) where soil moisture has been monitored from the time period 1996-1999. We subtracted these measured volumetric water contents from 0.5 , a typical value for the total porosity of unconsolidated sand (Pryor 1973) to get free air porosity as a function of depth. We used an exponential fit to the calculated free air porosities (Figure 2) as input into our $\mathrm{CO}_{2}$ productiondiffusion model.

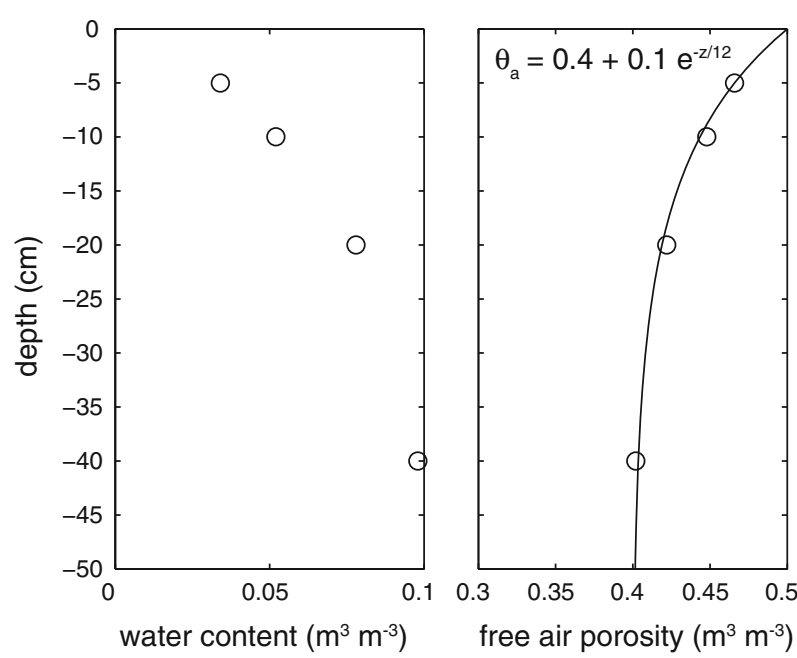

Figure 2. Profiles of soil water content and soil porosity. The water content profile shows the largest observed vertical change in water content at Deep Well, another SNWR site where soil moisture was measured continuously from 1996-1999 (Sevilleta LTER). These water contents were subtracted from a total porosity of 0.5 to estimate the maximum vertical change in free air porosity for the soils studied here. The equation for free air porosity that is shown was used to calculate the diffusion coefficient for $\mathrm{CO}_{2}$ in the soils.

We compared the effects of using two different functions for the production term in equation (1): an exponential function and a step function. The exponential function used was (Hesterberg and Siegenthaler 1991; Cerling 1999):

$$
P(z)=\mathrm{e}^{-z / z_{0}}
$$

where $z_{0}$ is the characteristic depth: $z_{0}=z_{\text {avg }} / 0.693$, and the step function was:

$$
\begin{gathered}
P(z)=0, \text { if } z<z_{\text {top }} \\
P(z)=R, \text { if } z_{\text {top }}<z<z_{\text {bot }} \\
P(z)=0, \text { if } z>z_{\text {bot }}
\end{gathered}
$$

where $z_{\text {top }}$ and $z_{\text {bot }}$ refer to the shallowest and deepest depths, respectively, at which soil respiration occurs $z_{\text {avg }}=\left(z_{\text {top }}-z_{\text {bot }}\right) / 2$ and $R$ is a constant. The comparison was intended to test the effect of different depth distributions of respiration on calculated values of $z_{\text {avg. }}$.

The $\delta^{13} \mathrm{C}$ value of soil-respired $\mathrm{CO}_{2}$ was calculated from measured soil $\mathrm{CO}_{2}$ and atmospheric $\mathrm{CO}_{2}$ values using the following equation rearranged from Davidson (1995): 


$$
\delta_{\mathrm{J}}=\frac{\delta_{\mathrm{s}}-4.4+\frac{C_{\mathrm{a}}}{C_{\mathrm{s}}}\left(4.4-\delta_{\mathrm{a}}\right)}{1.0044\left(1-\frac{C_{\mathrm{a}}}{C_{\mathrm{s}}}\right)}
$$

where $\delta$ is the standard delta notation for carbon isotope compositions, $C$ is concentration and the subscripts $\mathrm{J}, \mathrm{a}$, and $\mathrm{s}$ refer to $\mathrm{CO}_{2}$ respired in the soil, $\mathrm{CO}_{2}$ in the atmosphere and soil pore space $\mathrm{CO}_{2}$, respectively. The technique of calculating $\delta^{13} \mathrm{C}_{\text {r-soil }}$ values using below-ground measurements yields the isotopic composition of $\mathrm{CO}_{2}$ produced in the soil while collection of soil gas in above-ground chambers (for example, Flanagan and others 1999) yields the isotopic composition of $\mathrm{CO}_{2}$ diffusing into the atmosphere. At steady state, these fluxes are identical. Under transient conditions, however, $\mathrm{CO}_{2}$ diffusing across the soil-atmosphere interface does not typically have the same $\delta^{13} \mathrm{C}$ value as $\mathrm{CO}_{2}$ produced in the soil. The concentration and isotopic composition of soil $\mathrm{CO}_{2}$ at depth change slowly and are therefore typically at steady state whereas profiles are more often transient near the surface (because soil temperature and soil moisture change more rapidly there). Therefore, chamber-based measurements provide high temporal resolution, but are likely to reflect a transient $\mathrm{CO}_{2}$ flux (Nickerson and Risk 2009; Moyes and others 2010). Equation (2) assumes steady state conditions, so we used soil $\mathrm{CO}_{2}$ collected from the four deepest wells at each site $(50-100 \mathrm{~cm})$ to calculate $\delta^{13} \mathrm{C}_{\text {r-soil }}$. Deep soil $\mathrm{CO}_{2}$ responds more slowly than does shallow $\mathrm{CO}_{2}$ to changes that occur near the surface so our technique is appropriate for investigating seasonal variation but not daily variation. In addition, deep soil $\mathrm{CO}_{2}$ is probably minimally influenced by the decomposition of litter at the soil surface.

\section{Vegetation Surveys and Organic Matter Analysis}

Vegetation surveys were conducted on July 26, 2007 to estimate the proportions of different plant species at each site. The number of individuals and cover class (an estimate of the percentage cover based on the following bins: $<1 / 32,1 / 32-1 / 16$, $1 / 16-1 / 8,1 / 8-1 / 4,1 / 4-1 / 2,1 / 2-3 / 4,>3 / 4)$ in a $1 \times 1 \mathrm{~m}$ square were determined for each species every $2 \mathrm{~m}$ along transects through a previously determined around $500 \mathrm{~m}^{2}$ area appropriate for each site. The carbon isotope composition of dried and powdered stem/leaf mixtures of each plant species were measured using a Costech Elemental Analyzer coupled with a Delta Plus Mass Spectrometer in the stable isotope laboratory at the
University of New Mexico. The carbon isotope composition of soil organic matter was measured using the same technique. Living roots were removed from the soil samples which were subsequently treated with $10 \% \mathrm{HCl}$ to remove calcium carbonate before analysis. A pure graphite standard was used to calibrate peak area as a measure of the weight fraction of organic carbon in soil samples (estimated error equals $\pm 0.25 \mathrm{wt} \%$ ). The concentration of organic carbon was then calculated based on the mass of soil analyzed and measured peak area.

\section{RESUlts}

Winter $\mathrm{CO}_{2}$ profiles were characterized by low measured $\mathrm{CO}_{2}$ concentrations $(<\sim 1,000$ and $<\sim 2,500 \mathrm{ppm} \mathrm{V}$ at the shrubland and woodland sites, respectively), little curvature and $\delta^{13} \mathrm{C}$ values that decrease gradually with depth, reaching the lightest measured values at depths below $50 \mathrm{~cm}$ (Figure 3). In contrast, profiles during warm, wet periods (summer and early autumn) were characterized by higher $\mathrm{CO}_{2}$ concentrations (up to $\sim 3,000$ and $\sim 8,000 \mathrm{ppm} \mathrm{V}$ at the shrubland and woodland sites, respectively) and more curvature than winter profiles and $\delta^{13} \mathrm{C}$ values that decrease abruptly with depth in the shallow subsurface but change little with depth below 20-30 cm (Figure 3). Profiles during dry, warm periods (late spring, summer) were similar to winter profiles except that $\mathrm{CO}_{2}$

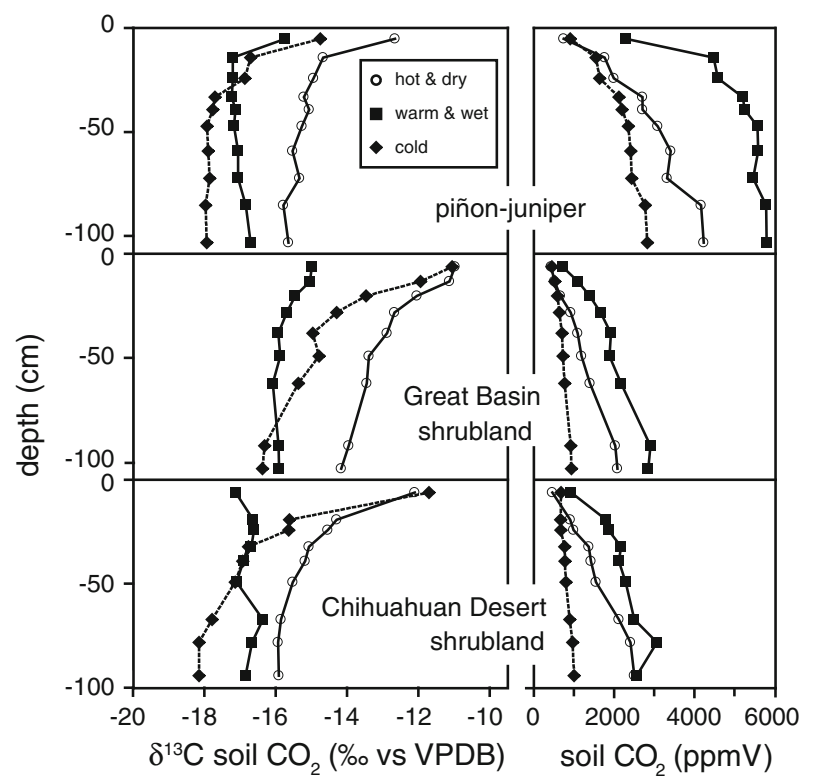

Figure 3. Characteristic soil $\mathrm{CO}_{2}$ profiles. Circles hot and dry episodes, squares warm, wet episodes, and diamonds cold episodes during the winter. 
concentration profiles have less curvature and the $\delta^{13} \mathrm{C}$ values during dry periods were higher at all depths than during the winter (Figure 3). All measured $\mathrm{CO}_{2}$ profiles were reported by Breecker and others (2009).

The soil at the piñon-juniper site has higher organic matter contents than the other soils, consistent with the observation of a darker and thicker $(20$ vs. $<5 \mathrm{~cm})$ ochric A horizon in this soil (Table 1). The soils at the Great Basin shrubland sites have organic matter contents below $0.1 \mathrm{wt} \%$ (Table 1). In general, the ecosystems studied consist of $\mathrm{C}_{4}$ grasses, which have the highest $\delta^{13} \mathrm{C}$ values, $\mathrm{C}_{3}$ shrubs or trees, which have intermediate $\delta^{13} \mathrm{C}$ values, and $\mathrm{C}_{3}$ forbs, which have the lowest $\delta^{13} \mathrm{C}$ values (Table 2). The Great Basin shrubland site has $\mathrm{C}_{4}$ shrubs with $\delta^{13} \mathrm{C}$ values higher than the $\delta^{13} \mathrm{C}$ values of grasses growing at the site (Table 2).

Compared with annual median values, the average depth of soil respiration in all soils studied was shallower following precipitation events, deeper during the coldest time of the year and deepest during the driest times of the year (Figure 4). Average depths of respiration in the shrublands during the first half of the study period (Septemeber 2006-June 2007) were shallower than during the second half of the study period (June 2007May 2008), when average depths of respiration in the shrubland soils were typically below $50 \mathrm{~cm}$ (Figure 4). $\mathrm{CO}_{2}$ measurements made in the top meter cannot be used to quantify average depths below about $60 \mathrm{~cm}$ assuming exponentially decreasing $\mathrm{CO}_{2}$ production and free air porosity because there is not enough curvature in the top meter of these soil $\mathrm{CO}_{2}$ profiles. Therefore, where the average depth of soil respiration is about $60 \mathrm{~cm}$ as shown in Figure 4, it is possible that the actual average depth of soil respiration was much greater. Furthermore, if the step function $\mathrm{CO}_{2}$ production equation is used instead of the exponentially decreasing production, calculated minimum average depths are deeper by 1.3-3 times; the average depths during the dry periods of 2007-2008 and are greater than $80 \mathrm{~cm}$. If a constant porosity of 0.4 is used, the best-fit average depths during the dry periods of 2007-2008 are greater than $1 \mathrm{~m}$.

Table 1. Soil Organic Matter Analyses (Top $20 \mathrm{~cm}$ )

\begin{tabular}{lcc}
\hline & $\delta^{13} \mathrm{C}(\%$ vs. VPDB $)$ & wt $\%$ TOC \\
\hline Piñon-juniper woodland $-17.7 \pm 2.5$ & $0.9 \pm 0.6$ \\
$\begin{array}{lll}\text { Chihuahuan Desert } \\
\text { shrubland }\end{array}$ & $-20.3 \pm 0.8$ & $0.4 \pm 0.2$ \\
Great Basin shrubland & $-19.1 \pm 0.4$ & $0.05 \pm 0.01$ \\
\hline
\end{tabular}

$\delta^{13} \mathrm{C}_{\mathrm{r}}$ values calculated by constructing soil $\mathrm{CO}_{2}$-based keeling plots and subtracting $4.4 \%$ from the $y$-intercept are generally within $\pm 0.2 \%$ of the values show in Figure 4. Estimated uncertainties (using Monte Carlo Simulations) of calculated $\delta^{13} \mathrm{C}_{\text {r-soil }}$ values are approximately $\pm 0.2 \%$ for samples in which $\mathrm{CO}_{2}$ concentrations are approximately 2,000 ppm V or greater and increase as $\mathrm{CO}_{2}$ concentrations decrease such that the uncertainties of winter and dry spring/summer $\delta^{13} \mathrm{C}_{\mathrm{r} \text {-soil }}$ values are approximately $\pm 1.0 \%$. The $\delta^{13} \mathrm{C}_{\text {r-soil }}$ values calculated from the soil $\mathrm{CO}_{2}$ data varied seasonally by $7-8 \%$ at the shrubland sites and by around $4 \%$ at the woodland site. $\delta^{13} \mathrm{C}_{\mathrm{r} \text {-soil }}$ values were highest in the summer and lowest in the winter. The values of $\delta^{13} \mathrm{C}_{\text {r-soil }}$ correlated well with both soil temperature (at $20 \mathrm{~cm}$ ) and vpd (Figure 5).

\section{Discussion}

The results of this study indicate that large variations in the average depth of respiration and the carbon isotope composition of soil-respired $\mathrm{CO}_{2}$ occur in all of the soils studied. The seasonal and interannual variations in the average depth and the $\delta^{13} \mathrm{C}$ value of soil-respired $\mathrm{CO}_{2}$ are especially large in the shrubland soils. In the shrubland soils $\mathrm{CO}_{2}$ concentration profiles during dry periods have little curvature in the top 1 meter, indicating deep respiration. Taken together, and as discussed below, the large variations in $\mathrm{z}_{\mathrm{avg}}$ and $\delta^{13} \mathrm{C}_{\mathrm{r} \text {-soil }}$ in the shrublands suggest that large changes occur in the relative activity of shrub roots at different soil depths.

\section{Soil $\mathrm{CO}_{2}$ and Soil-Respired $\mathrm{CO}_{2}$}

Large seasonal changes in $\delta^{13} \mathrm{C}_{\mathrm{r}-\text { soil }}$ values (as high as $8 \%$ ) were observed at each site (Figure 4 ), but the measured $\delta^{13} \mathrm{C}$ value of soil $\mathrm{CO}_{2}$ only varied by about $2 \%$ at each site (Figure 3 ). This occurs because low winter respiration rates nearly balance the effect of decreasing $\delta^{13} \mathrm{C}_{\mathrm{r}}$ values during the fall and winter. Low respiration rates cause a decrease in the amount of biogenic $\mathrm{CO}_{2}$ in the soil and a concomitant increase in the relative proportion of atmospheric $\mathrm{CO}_{2}$, which has a less negative $\delta^{13} \mathrm{C}$ value than biogenic $\mathrm{CO}_{2}$. Whereas respiration rates also decreased during dry episodes in the spring and summer during the period of study, the decrease was only sufficient to generate a significant effect from atmospheric mixing in March and May of 2008. Continued decrease of respiration rates could result in very high $\delta^{13} \mathrm{C}$ values of soil $\mathrm{CO}_{2}$ during the dry period of the spring and summer. 
Table 2. Vegetation $\delta^{13} \mathrm{C}$ Values (\%ovs. VPDB) and Percentage Cover

\begin{tabular}{|c|c|c|c|c|}
\hline Common name & Scientific name $^{1}$ & Type & $\delta^{13} \mathrm{C}$ & $\%$ cover \\
\hline \multicolumn{5}{|l|}{ Piñon-Juniper woodland } \\
\hline Juniper & Juniperus monosperma & Perrenial tree & -25.4 & 41 \\
\hline Piñon pine & Pinus edulis & Perrenial tree & -24.2 & 28 \\
\hline Gray oak & Quercus grisea & Perrenial tree & -27.2 & 17 \\
\hline Unknown legume & Fabaceae & Forb & -25.6 & 5 \\
\hline Black grama & Bouteloua eripoda & Perennial grass & -14.2 & 5 \\
\hline Blue grama & Bouteloua gracilis & Perennial grass & -14.8 & 5 \\
\hline Algerita & Berberis haematocarpa & Perrenial tree & -25.9 & 1 \\
\hline Unknown mustard & Brassicacae & Forb & -27.2 & 1 \\
\hline \multirow[t]{4}{*}{ Small-flowered milkvetch } & Astragalus nuttallianus & Annual forb & -28.0 & $<1$ \\
\hline & & Total & $-24.3^{2}$ & 103 \\
\hline & & $\mathrm{C}_{3}$ & $-25.4^{2}$ & 93 \\
\hline & & $\mathrm{C}_{4}$ & $-14.5^{2}$ & 10 \\
\hline \multicolumn{5}{|l|}{ Great Basin shrubland } \\
\hline Mormon tea & Ephedra viridis & Perennial shrub & -23.2 & 5 \\
\hline Fourwing saltbush & Atriplex canescens & Perennial shrub & -13.7 & 5 \\
\hline Honey mesquite & Prosopis glandulosa & Perennial shrub & -25.8 & 4 \\
\hline Shadscale saltbush & Atriplex confertifolia & Perennial shrub & -14.2 & 3 \\
\hline Galleta grass & Pleuraphis jamesii & Perennial grass & -14.5 & 2 \\
\hline Broom dalea & Psorothamnus scoparius & Perennial shrub & -24.3 & 1 \\
\hline Bladderpod mustard & Physaria gordonii & Annual forb & -26.9 & 1 \\
\hline Unknown & & Perennial forb & -28.8 & 1 \\
\hline Fluff grass & Erioneuron pulchellum & Perennial grass & -15.3 & 1 \\
\hline Sand dropseed & Sporobolus cryptandrus & Perennial grass & -13.9 & 1 \\
\hline Spectacle pod & Dimorphocarpa wislizenii & Annual forb & -26.9 & 1 \\
\hline \multirow[t]{2}{*}{ Desert zinnia } & Zinnia grandiflora & Perennial forb & -27.5 & 1 \\
\hline & Xanthisma spinosa & Perennial forb & -26.7 & $<1$ \\
\hline Broom snakeweed & Gutierrezia sarothrae & Perennial forb & -25.9 & $<1$ \\
\hline Feather dalea & Dalea formosa & Perennial shrub & -25.2 & $<1$ \\
\hline Fineleaf hymenopappus & Filifolius hymenopappus & Perennial forb & -26.3 & $<1$ \\
\hline Blackfoot daisy & Melampodium leucanthum & Perennial forb & -25.8 & $<1$ \\
\hline Chamisa & Ericameria naseousus & Perennial shrub & -26.9 & $<1$ \\
\hline \multirow[t]{4}{*}{ Hairyseed bahia } & Bahia absinthifolia & Perennial forb & -25.9 & $<1$ \\
\hline & & Total & $-20.7^{2}$ & 26 \\
\hline & & $\mathrm{C}_{3}$ & $-25.2^{2}$ & 15 \\
\hline & & $\mathrm{C}_{4}$ & $-14.1^{2}$ & 12 \\
\hline \multicolumn{5}{|c|}{ Chihuahuan Desert shrubland ${ }^{3}$} \\
\hline Creosote bush & Larrea tridentata & Perennial shrub & -26.0 & \\
\hline Broom snakeweed & Gutierrezia sarothrae & Perennial forb & -28.1 & \\
\hline White horsenettle & Solanum elaegnifolium & Perennial forb & -29.4 & \\
\hline Honey mesquite & Prosopis glandulosa & Perennial shrub & -24.6 & \\
\hline Fluff grass & Erioneuron pulchellum & Perennial grass & -15.5 & \\
\hline \multirow[t]{2}{*}{ Bush muhly } & Muhlenbergia porteri & Perennial grass & -15.3 & \\
\hline & Cryptanthus pusila & Annual forb & -28.5 & \\
\hline Unknown mustard & Brassicacae & Forb & -28.5 & \\
\hline Unknown mustard & Brassicacae & Forb & -28.9 & \\
\hline $\begin{array}{l}{ }^{1} \text { Plants identified by } T . \text { Lowrey. } \\
{ }^{2} \text { Mean } \delta^{13} C \text { values weighted accordir } \\
{ }^{3} \text { Nearly monospecific, vegetation surv }\end{array}$ & rcent cover. & & & \\
\hline
\end{tabular}

These observations and theoretical considerations indicate that the $\delta^{13} \mathrm{C}$ value of soil $\mathrm{CO}_{2}$ in these soils is controlled by both the rate of respiration and the value of $\delta^{13} \mathrm{C}_{\mathrm{r} \text {-soil }}$ although it is possible that other factors such as carbon isotope fractionation associated with transient state diffusion (for example, Brüggemann and others 2011) influence the $\delta^{13} \mathrm{C}$ values of $\mathrm{CO}_{2}$ in these soils. The cause of seasonal variation in $\delta^{13} \mathrm{C}_{\mathrm{r}}$ values is discussed below. 

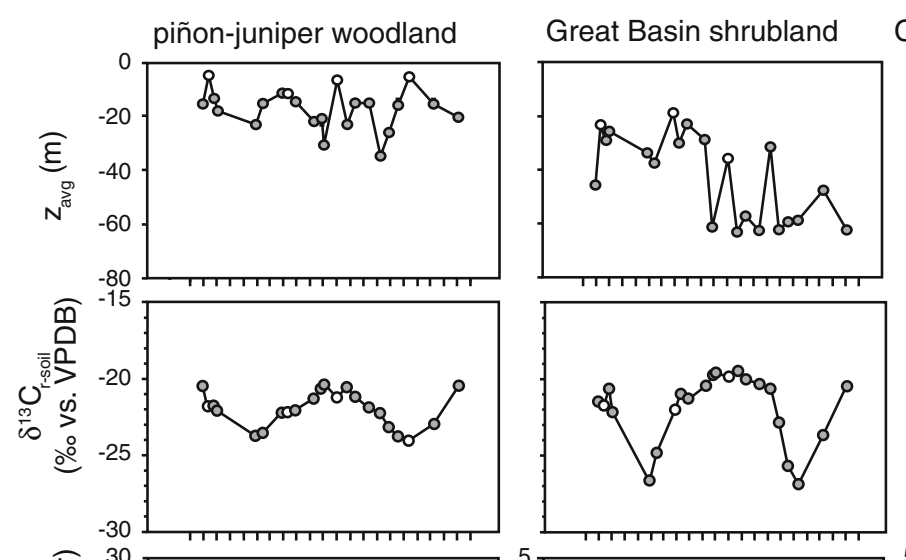

Chihuahuan Desert shrubland
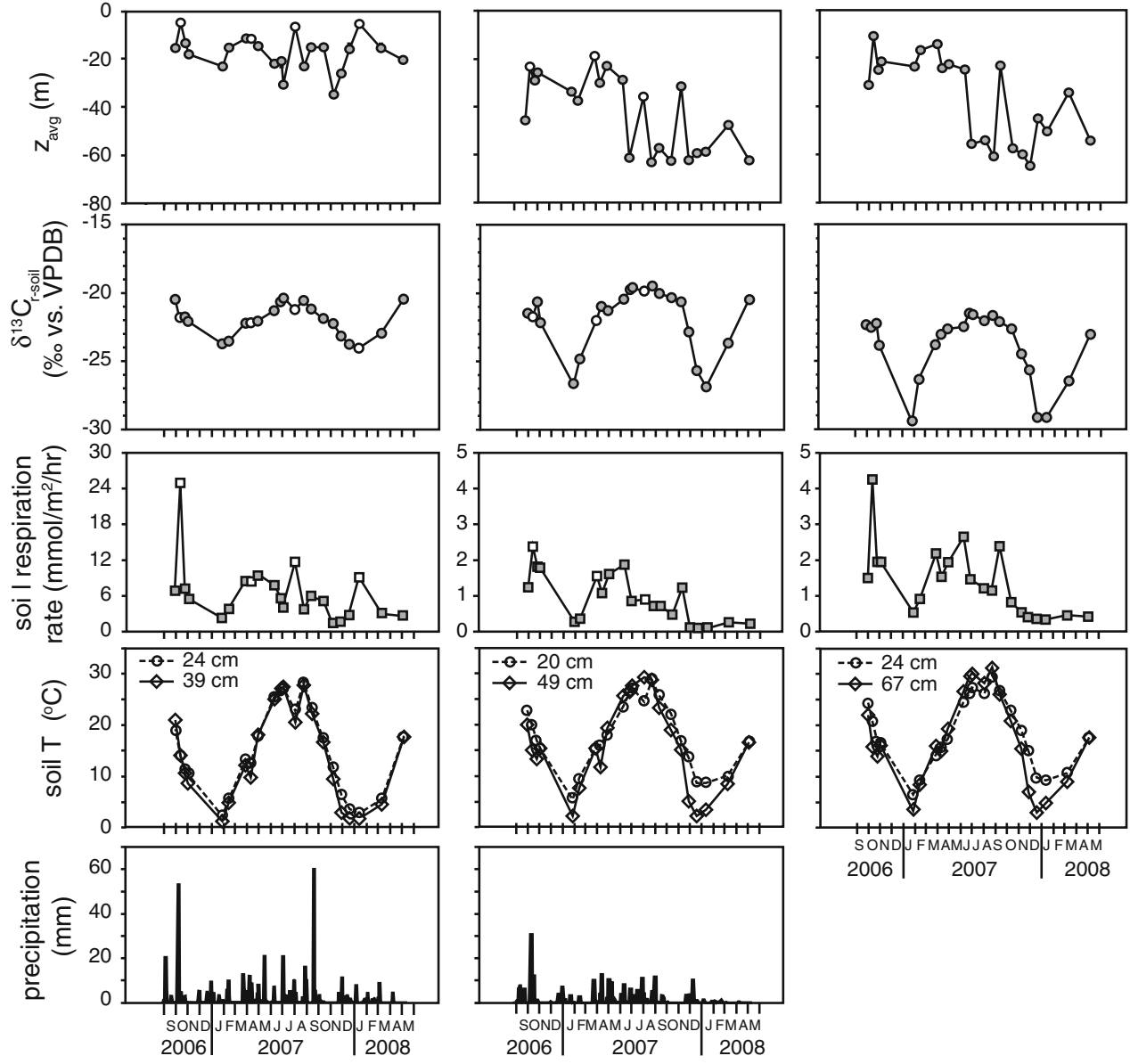

Figure 4. Time series of $\delta^{13} \mathrm{C}_{\mathrm{r} \text {-soil }}, \mathrm{z}_{\mathrm{avg}}$, soil respiration rate, soil temperature, and precipitation. $\delta^{13} \mathrm{C}_{\mathrm{r}-\mathrm{soil}}, \mathrm{z}_{\mathrm{avg}}$, and soil respiration rate were calculated using measured concentrations and $\delta^{13} \mathrm{C}$ values of pore space soil $\mathrm{CO}_{2}$ as discussed in the methods section of the text. Estimates of minimum (shallowest) values for $z_{\text {avg }}$ and maximum values for respiration rate are shown. Values for $z_{\text {avg }}$ were calculated assuming an exponential decrease in soil respiration rates with depth because this resulted in shallower values than the step function described in the text. Soil temperatures are shown for $\sim 20 \mathrm{~cm}$ and for the depth of measurement closest to the deepest calculated values of $z_{\text {avg }}$ for each soil. Note change in scale between woodland and shurbland plots of soil respiration rate. Open symbols indicate samples likely influenced by pulse precipitation $(>1 \mathrm{~cm}$ of precipitation was recorded during the 5 days prior to sampling collection). Precipitation was measured at meteorological stations maintained by D. Moore in association with the Sevilleta Long Term Ecological Research Project. No precipitation data are reported for the Chihuahuan Desert Shrubland site because there are no meteorological stations in sufficient proximity.

\section{The Source of Between-Pulse Soil-Respired $\mathrm{CO}_{2}$}

We argue that the large seasonal variation of $\delta^{13} \mathrm{C}_{\mathrm{r} \text {-soil }}$ values observed in this study result from changes in the magnitude of photosynthetic discrimination that are expressed in rhizosphere respiration and that between-pulse soil-respired $\mathrm{CO}_{2}$ is almost entirely autotrophic. Before we discuss the evidence for this explanation, we first eliminate other potential explanations for seasonal variations in the values of $\delta^{13} \mathrm{C}_{\mathrm{r} \text {-soil }}$ : (1) a change from $\mathrm{C}_{3}$ - to $\mathrm{C}_{4}$-dominated rhizosphere respiration, (2) variable mixing ratios of biogenic $\mathrm{CO}_{2}$ with $\mathrm{CO}_{2}$ from a geologic source (that is, magmatic $\mathrm{CO}_{2}$ or $\mathrm{CO}_{2}$ from dissolution/precipitation of calcite), (3) a change in the vertical distribution of decomposition rates, (4) changes in the $\delta^{13} \mathrm{C}$ value of soil organic matter, (5) changes in the relative decomposition rates of different organic substrates (substrate shift), and (6) variable proportions of rhizosphere respiration and decomposition.

Mechanism 1 (change in $\mathrm{C}_{3} / \mathrm{C}_{4}$ respiration) is perhaps the most obvious potential explanation for seasonally variable $\delta^{13} \mathrm{C}_{\mathrm{r} \text {-soil }}$ values in mixed $\mathrm{C}_{3}-\mathrm{C}_{4}$ 

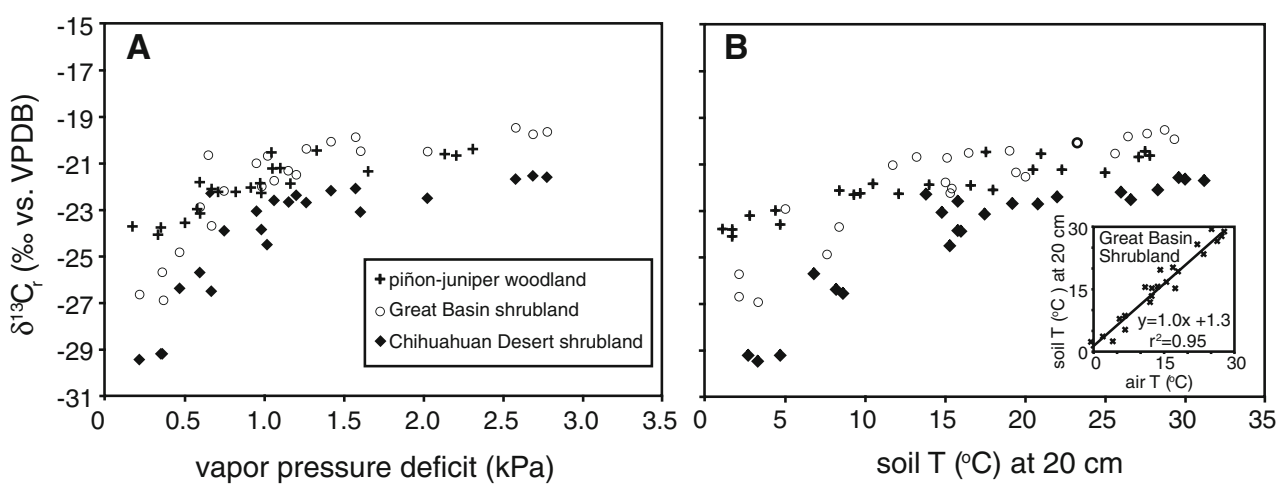

Figure 5. $\delta^{13} \mathrm{C}_{\mathrm{r}-\text { soil }}$ versus vapor pressure deficit (a) and soil temperature (b). The inset in (b) shows the correlation between soil temperature and mean air temperature over the previous 2 weeks. communities. However, mechanism 1 does not provide a satisfying explanation because there is no correlation between the fraction of $\mathrm{C}_{4}$ vegetation and the magnitude of the observed changes in values of $\delta^{13} \mathrm{C}_{\mathrm{r} \text {-soil }}$. For instance, a similar seasonal shift in $\delta^{13} \mathrm{C}_{\mathrm{r} \text {-soil }}$ values is observed at the Chihuahuan Desert site, where $\mathrm{C}_{4}$ plants constitute a very small fraction of vegetative cover (the site is nearly monospecific, dominated by the $\mathrm{C}_{3}$ shrub L. tridentata), and the Great Basin shrubland site, where $\mathrm{C}_{4}$ plants constitute approximately $50 \%$ of the vegetative cover. Whereas mean annual $\delta^{13} \mathrm{C}_{\mathrm{r} \text {-soil }}$ values do correlate with the relative abundance of $\mathrm{C}_{3}$ and $\mathrm{C}_{4}$ vegetation (mean $\delta^{13} \mathrm{C}_{\mathrm{r} \text {-soil }}$ values are higher at the Great Basin shrubland site than at the Chihuahuan Desert site), the seasonal variation of $\delta^{13} \mathrm{C}_{\mathrm{r} \text {-soil }}$ values measured in this study must be explained by some other process. It remains possible that seasonal changes in $\mathrm{C}_{3}-\mathrm{C}_{4}$ productivity drive variations in $\delta^{13} \mathrm{C}$ value of $\mathrm{CO}_{2}$ respired in the shallow subsurface of these soils $\left(<20 \mathrm{~cm}\right.$, where the root density of $\mathrm{C}_{4}$ grasses is the highest) but such variations would require higher temporal resolution data to resolve.

The biannual (winter and dry periods during the summer) decrease in soil $\mathrm{CO}_{2}$ concentrations allows the potential for a geologic source of $\mathrm{CO}_{2}$ (mechanism 2) to be evaluated. We need to consider magmatic $\mathrm{CO}_{2}$ as a possible source in the soils we studied given the evidence for a deep $\mathrm{CO}_{2}$ source and the location of our study area in proximity to a magma chamber beneath Socorro, New Mexico (Sandford and others 1977). A small, but presumably constant contribution from a deep magmatic source with a relatively high $\delta^{13} \mathrm{C}$ value $(\sim-6 \%$, compared to biological sources which have $\delta^{13} \mathrm{C}$ values $<-12 \%$ ) would be discernible as the biologic flux diminishes. The large range in $\delta^{13} \mathrm{C}_{\mathrm{r} \text {-soil }}$ values when soil $\mathrm{CO}_{2}$ concentrations are low indicate that a negligible component of the betweenpulse $\mathrm{CO}_{2}$ produced at depth in these soils originates from a magmatic source. Inorganic carbon in these soils is another potential abiotic source of $\mathrm{CO}_{2}$. Calcite in these soils has a $\delta^{13} \mathrm{C}$ value of around $0 \%$. The low $\delta^{13} \mathrm{C}_{\mathrm{r} \text {-soil }}$ values measured in this study are consistent with entirely biological $\mathrm{CO}_{2}$ sources and indicate that the contribution of $\mathrm{CO}_{2}$ evolved from calcite is minimal, even though the abiotic contribution cannot be quantified. The dominance of the biological $\mathrm{CO}_{2}$ flux over the carbonate weathering $\mathrm{CO}_{2}$ flux, even in dryland soils containing abundant calcium carbonate, is also supported by results from Serna-Pérez and others (2006). Pulse precipitation may result in the production of $\mathrm{CO}_{2}$ from the solution and eventual precipitation of calcite in soils but it is currently unclear whether or not this flux constitutes a significant component of total soil respiration after precipitation events.

Low organic carbon contents occur in these soils because they experience high temperatures on a seasonal basis and contain high concentrations of oxidative enzymes (Stursova and Sinsabaugh 2008). Rapid oxidation of organic matter indicates that decomposition rates are probably limited by litter input rates, especially at depth. High decomposition rates could potentially be supported near the surface in these soils but decomposition is probably very minor at depth where litter input is small. Combining the observation that the average depth of respiration in the shrubland soils is almost always greater than $20 \mathrm{~cm}$ and frequently greater than $50 \mathrm{~cm}$ with the argument that decomposition is probably minimal at depth suggests that the contribution of decomposition to the measured soil respiration is minor. Therefore, mechanisms 3-6 are not the most realistic explanations for changes in $\delta^{13} \mathrm{C}_{\mathrm{r} \text {-soil. }}$.

There is additional evidence against mechanisms 3-6. The lack of a correlation between the average depth of respiration and values of $\delta^{13} \mathrm{C}_{\mathrm{r} \text {-soil }}$ in the woodland soil studied here (Figure 6) suggests that a change in the vertical distribution of decomposition (mechanism 3) is not the primary cause of the observed variation in $\delta^{13} \mathrm{C}_{\mathrm{r} \text {-soil }}$. The observation 
that the average depth of respiration is below $50 \mathrm{~cm}$ during dry periods when $\delta^{13} \mathrm{C}_{\mathrm{r} \text {-soil }}$ values are least negative and during cold periods when $\delta^{13}$ $\mathrm{C}_{\mathrm{r} \text {-soil }}$ values are most negative precludes mechanism 4 because it is highly unlikely that the $\delta^{13} \mathrm{C}$ value of soil organic matter at greater than $50 \mathrm{~cm}$ depth changes by $8 \%$ on a seasonal basis. In the shrublands, the $\delta^{13} \mathrm{C}_{\mathrm{r} \text {-soil }}$ values during the winters of 2006-2007 and 2007-2008 were similar (minimum values occurred in January and were -26.7 and -26.9 for GBS and -29.5 and -29.2 for CDS in 2007 and 2008, respectively) but the average depths of respiration were deeper, and the soil temperatures at the average depths of respiration were more than $6^{\circ} \mathrm{C}$ warmer during the winter of 2007-2008 than the previous winter (Figure 4). Therefore, a soil temperature control on the heterotrophic microbial community and the substrate decomposed by it (mechanism 5) is not the best explanation for variations in $\delta^{13} \mathrm{C}_{\mathrm{r} \text {-soil }}$ values. Furthermore, a temperature-driven heterotrophic control on $\delta^{13} \mathrm{C}_{\text {r-soil }}$ would require a sensitivity that is at least two times higher in the shrublands than in the woodland soil because seasonal soil temperature variations in the woodland and shrubland soils are similar but seasonal variations in $\delta^{13} \mathrm{C}_{\mathrm{r} \text {-soil }}$ values are two times larger in the shrubland soils. A substrate shift from labile, relatively less ${ }^{13} \mathrm{C}$-depleted root exudates to recalcitrant, more ${ }^{13} \mathrm{C}$-depleted (Park and Epstein 1961; Benner and others 1987) organic compounds as photosynthesis, and thus the delivery of labile photosynthate to the rhizosphere, decreases cannot explain the observed variation in $\delta^{13} \mathrm{C}_{\text {r-soil }}$. Although $\delta^{13} \mathrm{C}_{\mathrm{r} \text {-soil }}$ values are relatively low when the rate of photosynthesis is low in the winter, $\delta^{13} \mathrm{C}_{\mathrm{r} \text {-soil }}$ values are at the high end of the observed range when the rate of photosynthesis is low during the dry part of the late spring/early summer.

The $\delta^{13} \mathrm{C}$ value of organic matter in the soils studied is approximately equal to or slightly higher than the highest $\delta^{13} \mathrm{C}_{\mathrm{r} \text {-soil }}$ values measured. Therefore, an increase in the relative contribution of decomposition to total soil respiration (mechanism 6) with increasing temperature could explain the approach of $\delta^{13} \mathrm{C}_{\mathrm{r} \text {-soil }}$ toward the $\delta^{13} \mathrm{C}$ value of soil organic matter. However, when compared with decomposition, rhizosphere respiration is thought to be more sensitive to temperature (Boone and others 1998), in which case $\delta^{13} C_{\text {r-soil }}$ values should approach the $\delta^{13} \mathrm{C}$ value of soil organic matter as temperature decreases, not as temperature increases.

We argue that seasonal changes in the magnitude of photosynthetic discrimination during $\mathrm{C}_{3}$ photosynthesis are primarily responsible for the

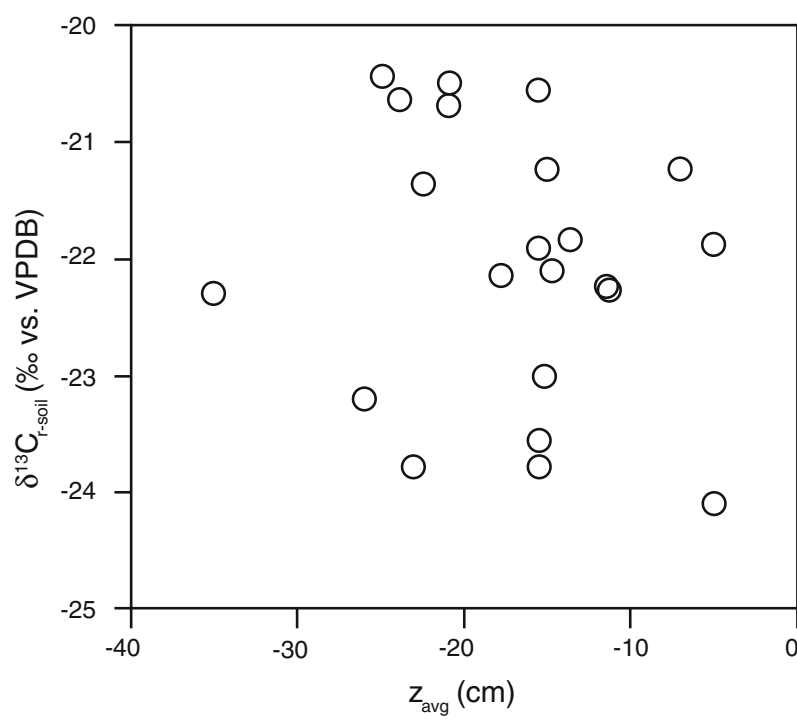

Figure 6. Average depth of respiration versus $\delta^{13} \mathrm{C}_{\mathrm{r} \text {-soil }}$ in the piñon-juniper woodland soil. The absence of a correlation indicates that changes in the relative rates of soil organic matter decomposition at different soil depths do not cause the observed changes in $\delta^{13} \mathrm{C}_{\mathrm{r} \text {-soil }}$.

observed variability in $\delta^{13} \mathrm{C}_{\text {r-soil }}$. This interpretation is strongly supported by the correlation between vpd and $\delta^{13} \mathrm{C}_{\mathrm{r} \text {-soil }}$ (Figure 5). We argue that the correlation between $20 \mathrm{~cm}$ soil temperature and $\delta^{13} \mathrm{C}_{\mathrm{r} \text {-soil }}$ is not causal, but instead occurs because shallow soil temperature correlates with air temperature (Figure 5) and air temperature largely controls vpd. The argument for a stomatal control of $\delta^{13} \mathrm{C}_{\mathrm{r} \text {-soil }}$ is further supported by the similar relationship between vpd and the $\delta^{13} \mathrm{C}$ value of ecosystem respiration that has been observed in conifer forests of western Oregon, where $\mathrm{C}_{4}$ plants are absent (Bowling and others 2002) (Figure 7).

The arguments above suggest that the betweenpulse $\mathrm{CO}_{2}$ in soils studied here is primarily produced by rhizosphere respiration. Without knowing the total range of pure autotrophic $\delta^{13} \mathrm{C}_{\mathrm{r}}$ values for each soil, we cannot quantitatively partition total soil respiration into its autotrophic and heterotrophic components using the carbon isotope data presented here. However, we suggest that the observed $8 \%$ range is almost as large as the total autotrophic range in $\delta^{13} \mathrm{C}_{\mathrm{r}}$ values and therefore that autotrophic respiration dominates in these soils. The smaller range of $\delta^{13} \mathrm{C}_{\mathrm{r} \text {-soil }}$ values at the piñon-juniper site in comparison to the other sites likely results from decomposition attenuating the seasonal change in $\delta^{13} \mathrm{C}_{\mathrm{r}-\text { soil }}$ values caused by rhizosphere respiration. The higher organic matter content in the soil at the piñon-juniper site 


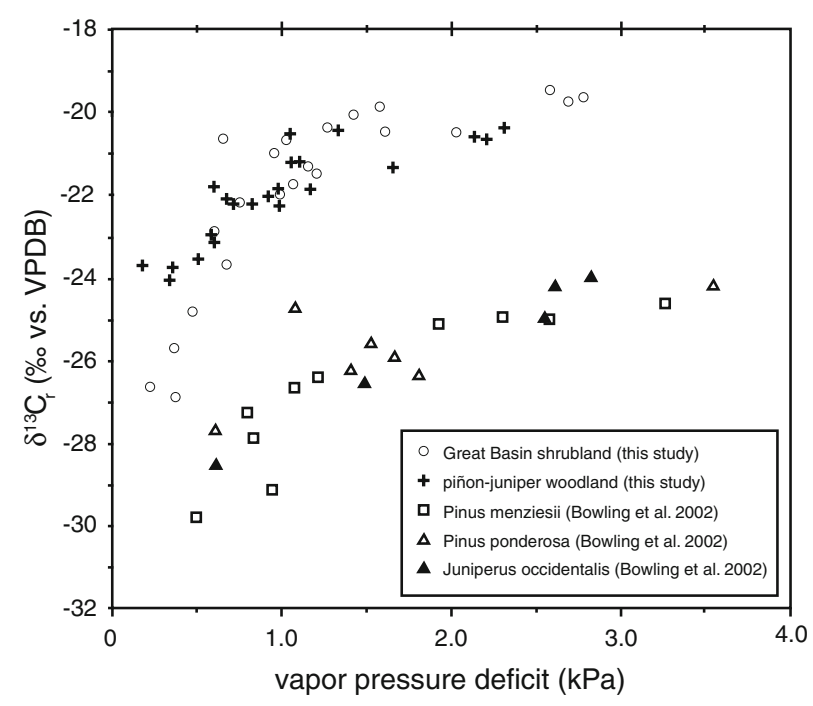

Figure 7. Comparison of the relationship between $\delta^{13} \mathrm{C}_{\mathrm{r}}$ and vapor pressure deficit (vpd) observed in different ecosystems. $\delta^{13} \mathrm{C}_{\mathrm{r}}$ values from Bowling and others (2002) are for total ecosystem respiration and were interpreted to reflect changes in the magnitude of photosynthetic discrimination. The correlation with vpd and the similarity of the soil-respired $\mathrm{CO}_{2}$ curves from this study with the ecosystem-respired $\mathrm{CO}_{2}$ curves from Bowling and others (2002) support the conclusion that the magnitude of photosynthetic discrimination controls $\delta^{13} \mathrm{C}_{\mathrm{r} \text {-soil }}$ in the soils studied.

supports this interpretation. $\mathrm{CO}_{2}$ from 50 to $100 \mathrm{~cm}$ depth in the shrubland soils, however, likely provides a unique opportunity to study rhizosphere respiration minimally diluted by SOM decomposition.

Heterotrophic respiration in the shallow subsurface is thought to respond quickly to pulse precipitation and to dominate the soil-to-atmosphere $\mathrm{CO}_{2}$ flux during small precipitation events (Austin and others 2004; Schwinning and Sala 2004). The origin of $\mathrm{CO}_{2}$ respired during pulse events is more difficult to characterize using stable carbon isotope ratios than is the origin of between-pulse $\mathrm{CO}_{2}$ due to isotope fractionation associated with the transient nature of pulse events (Nickerson and Risk 2009; Moyes and others 2010). These difficulties should be addressed at some point. However, the majority of annually integrated total ecosystem respiration occurs between, not during, pulse events; in shrubland ecosystems in central New Mexico approximately $85 \%$ of total annual ecosystem respiration occurs between pulse events (Litvak unpublished data). Therefore, the results of the present study suggest that the majority of $\mathrm{CO}_{2}$ respired annually by these desert shrubland ecosystems is autotrophic in origin and is sourced directly from recent photosynthate. Combined with the low organic matter contents in these soils, dominance of autotrophic respiration indicates carbon is rapidly and efficiently cycled through these shrubland ecosystems; a substantial portion of the carbon must have a mean residence time that approaches the transport time of photosynthate from leaves to roots.

\section{Conclusions}

Measurements of the depth of soil respiration and the carbon isotope composition of respired $\mathrm{CO}_{2}$ can be used to study soil respiration and its sources. The observed large variations in the depth of respiration and $\delta^{13} \mathrm{C}_{\text {r-soil }}$ values are best explained by root/ rhizosphere respiration expressing changes in the magnitude of photosynthetic discrimination during $\mathrm{C}_{3}$ photosynthesis. We therefore conclude that the between-pulse flux of $\mathrm{CO}_{2}$ from these soils is largely autotrophic and not from decomposition of soil organic matter, weathering of calcium carbonate or from a magmatic source. Smaller variations in the depth of respiration and $\delta^{13} \mathrm{C}_{\text {r-soil }}$ values at the piñon-juniper site can be explained by dilution of autotrophic $\mathrm{CO}_{2}$ by decomposition in the $\mathrm{A}$ horizon of that soil. If $\mathrm{CO}_{2}$ respired in the shrubland soils is primarily autotrophic in origin, then the relative activity of shrub roots at different depths must change seasonally and interannually, perhaps due to preferential allocation of photosynthate to roots at different soil depths, and the shrubland soils should be considered as excellent natural laboratories for the study of rhizosphere respiration. We also conclude that carbon is rapidly and efficiently cycled through these ecosystems (especially the shrublands). Given that the biomes we studied are representative of regional vegetation and that seasonal variations in vapor pressure deficit are largely temperature driven and therefore regionally consistent, it is likely that $\delta^{13} \mathrm{C}$ values of $\mathrm{CO}_{2}$ respired from soils across much of the southwestern United States change seasonally by at least $4 \%$.

\section{ACKNOWLEDGMENTS}

Thanks to the Sevilleta National Wildlife Refuge for providing access, D. Moore for meteorological data, T. Lowrey for identifying plant samples, J. Barnes and J. Dodd for help with sample collection, L. Roberts for assistance with vegetation surveys and to two anonymous reviewers. 


\section{OPEN ACCESS}

This article is distributed under the terms of the Creative Commons Attribution Noncommercial License which permits any noncommercial use, distribution, and reproduction in any medium, provided the original author(s) and source are credited.

\section{REFERENCES}

Anderson-Teixeira KJ, DeLong JP, Fox AM, Brese DA, Litvak ME. 2011. Differential responses of production and respiration to temperature and moisture drive the carbon balance across a climatic gradient in New Mexico. Global Chang Biol 17:410-24.

Andrews JA, Matamala R, Westover KM, Schlesinger WH. 2000. Temperature effects on the diversity of soil heterotrophs and the $\delta^{13} \mathrm{C}$ of soil-respired $\mathrm{CO}_{2}$. Soil Biol Biochem 32:699-706.

Austin AT, Yahjian L, Stark JM, Belnap J, Porporato A, Norton U, Ravetta DA, Schaeffer SM. 2004. Water pulses and biogeochemical cycles in arid and semiarid ecosystem. Oecologia $141: 221-35$.

Benner R, Fogel ML, Sprague EK, Hodson RE. 1987. Depletion of ${ }^{13} \mathrm{C}$ in lignin and its implications for stable carbon isotope studies. Nature 329:708-10.

Bird RB, Stewart WE, Lightfoot EN. 1960. Transport phenomena. New York: Wiley.

Boone RD, Nadelhoffer KJ, Canary JD, Kaye JP. 1998. Roots exert a strong influence of the temperature sensitivity of soil respiration. Nature 396:570-2.

Bowling DR, McDowell NG, Bond BJ, Law BE, Ehleringer JR. 2002. ${ }^{13} \mathrm{C}$ content of ecosystem respiration is linked to precipitation and vapor pressure deficit. Oecologia 131:113-24.

Breecker D, Sharp ZD. 2008. A field and laboratory method for monitoring the concentration and stable isotope composition of soil $\mathrm{CO}_{2}$. Rapid Commun Mass Spectrom 22:449-54.

Breecker D, Sharp ZD, McFadden L. 2009. Seasonal bias in the formation and stable isotope composition of pedogenic carbonate in modern soils from central New Mexico, USA. Bull Geol Soc Am 121:630-40.

Brüggemann N, Gessler A, Kayler Z, Keel SG, Badeck F, Barthel M, Boeckx P, Buchmann N, Brugnoli E, Esperschütz J, Gavrichkova O, Ghashghaie J, Gomez-Casanovas N, Keitel C, Knohl A, Kuptz D, Palacio S, Salmon Y, Uchida Y, Bahn M. 2011. Carbon allocation and carbon isotope fluxes in the plant-soil-atmosphere continuum: a review. Biogeosciences Discussions 8:3619-95.

Cerling TE. 1999. Stable carbon isotopes in palaeosol carbonates. In: Thiry $M$, Simon-Coincon R, Eds. Palaeoweathering, palaeosurfaces and related continental deposits. Oxford: Blackwell, Special Publication of the International Association of Sedimentologists, pp 43-60.

Cook FJ, Thomas SM, Kelliher FM. 1998. A model of onedimensional steady-state carbon dioxide diffusion from soil. Ecol Model 109:155-64.

Davidson EA, Janssens IA. 2006. Temperature sensitivity of soil carbon decomposition and feedbacks to climate change. Nature 440:165-73.

Davidson EA, Savage KE, Trumbore SE, Borken W. 2006. Vertical partitioning of $\mathrm{CO}_{2}$ production within a temperature forest soil. Global Chang Biol 12:944-56.
Davidson GR. 1995. The stable isotope composition and measurement of carbon in soil $\mathrm{CO}_{2}$. Geochim Cosmochim Acta 59:2485-9.

de Jong E, Schappert HJV. 1972. Calculation of soil respiration and activity from $\mathrm{CO}_{2}$ profiles in the soil. Soil Sci 113:328-33.

Dörr H, Münnich KO. 1990. 222Rn flux and soil air concentration profiles in West-Germany. Soil $222 \mathrm{Rn}$ as a tracer for gas transport in the unsaturated soil zone. Tellus 42B:20-8.

Drewitt GB, Black TA, Jassal RS. 2005. Using measurements of soil $\mathrm{CO}_{2}$ efflux and concentrations to infer the depth distribution of $\mathrm{CO}_{2}$ production in a forest soil. Can J Soil Sci 85:213-21.

Ehleringer JR. 1978. Implications of quantum yield differences to the distributions of $\mathrm{C}_{3}$ and $\mathrm{C}_{4}$ grasses. Oecologia 31:255-67.

Ehleringer JR, Cerling TE, Helliker BR. 1997. $\mathrm{C}_{4}$ photosynthesis, atmospheric $\mathrm{CO}_{2}$, and climate. Oecologia 112:285-99.

Ekblad A, Högberg P. 2001. Natural abundance of ${ }^{13} \mathrm{C}$ in $\mathrm{CO}_{2}$ respired from forest soils reveals speed of link between tree photosynthesis and root respiration. Oecologia 127:305-8.

Farquhar GD, Ehleringer JR, Hubick KT. 1989. Carbon isotope discrimination and photosynthesis. Ann Rev Plant Physiol Plant Mol Biol 40:503-37.

Fessenden JE, Ehleringer JR. 2003. Temporal variation in $\mathrm{d}^{13} \mathrm{C}$ of ecosystem respiration in the Pacific Northwest: links to moisture stress. Oecologia 136:129-36.

Fierer N, Chadwick OA, Trumbore SE. 2005. Production of $\mathrm{CO}_{2}$ in soil profiles of a California annual grassland. Ecosystems 8:412-29.

Flanagan LB, Kubien DS, Ehleringer JR. 1999. Spatial and temporal variation in the carbon and oxygen stable isotope ratio of respired $\mathrm{CO}_{2}$ in a boreal forest ecosystem. Tellus 51B:367-84.

Gibbens RP, Lenz JM. 2001. Root systems of some Chihuahuan Desert plants. J Arid Environ 49:221-63.

Gile LH, Gibbens RP, Lenz JM. 1998. Soil-induced variability in root systems of creosotebush (Larrea tridentata) and tarbush (Flourensia cernua). J Arid Environ 39:57-78.

Hartle RT, Fernandez GCJ, Nowak RS. 2006. Horizontal and vertical zones of influence fro root systems of four Mojave Desert shrubs. J Arid Environ 64:586-603.

Hashimoto S, Tanaka N, Kume T, Yoshifuji N, Hotta N, Tanaka K, Suzuki M. 2007. Seasonality of vertically partitioned soil $\mathrm{CO}_{2}$ production in temperature and tropical forest. J For Res 12:209-21.

Hesterberg R, Siegenthaler U. 1991. Production and stable isotopic composition of $\mathrm{CO}_{2}$ in a soil near Bern, Switzerland. Tellus Series B Chem Phys Meteorol 43:197.

Hirsch AI, Trumbore SE, Goulden M. 2002. Direct measurements of the deep soil respiration accompanying seasonal thawing of a boreal forest soil. J Geophys Res 108:8221.

Högberg P, Nordgren A, Buchmann N, Taylor AFS, Ekblad A, Högberg MN, Nyberg G, Ottosson-Löfvenius M, Read DJ. 2001. Large scale forest girdling shows that current photosynthesis drives soil respiration. Nature 411:789-92.

Hut G. 1987. Consultant's group meeting on stable isotope reference samples for geochemical and hydrological investigations. Vienna: International Atomic Energy Agency.

Kemp PR, Williams GJ. 1980. A physiological basis for niche separation between Agropyron smythii $\left(\mathrm{C}_{3}\right)$ and Bouteloua gracilis $\left(\mathrm{C}_{4}\right)$. Ecology 61:846-58.

Lai C-T, Riley W, Owensby C, Ham J, Schauer A, Ehleringer JR. 2006. Seasonal and interannual variations of carbon and oxygen isotopes of respired $\mathrm{CO}_{2}$ in a tallgrass prairie: 
measurements and modeling results from 3 years with contrasting water availability. J Geophys Res 111:D08S06.

McDowell NG, Bowling DR, Bond BJ, Irvine J, Law BE, Anthoni P, Ehleringer JR. 2004a. Response of the carbon isotopic content of ecosystem, leaf, and soil respiration to meteorological and physiological driving factors in a Pinus ponderosa ecosystem. Global Biogeochem Cycles 18:GB1013.

McDowell NG, Bowling DR, Schauer A, Irvine J, Bond BJ, Law BE, Ehleringer JR. 2004b. Associations between carbon isotope ratios of ecosystem respiration, water availability and canopy conductance. Global Chang Biol 10:1767-84.

Melillo JM, Aber JD, Linkins AE, Ricca A, Fry B, Nadelhoffer KJ. 1989. Carbon and nitrogen dynamics along the decay continuum: plant litter to soil organic matter. Plant Soil 115:189-98.

Moldrup P, Olesen T, Gamst J, Schjonning P, Yamaguchi T, Rolston DE. 2000. Predicting the gas diffusion coefficient in repacked soil: water-induced linear reduction model. Soil Sci Soc Am J 64:1588-94.

Moyes AB, Gaines SJ, Siegwolf RTW, Bowling DR. 2010. Diffusive fractionation complicates isotopic partitioning of autotrophic and heterotrophic sources of soil respiration. Plant Cell Environ 33:1804-19.

Nadelhoffer KJ, Fry B. 1988. Controls on natural nitrogen-15 and carbon-13 abundances in forest soil organic matter. Soil Sci Soc Am J 52:1633-40.

Nickerson N, Risk D. 2009. Physical controls on the isotopic composition of soil-respired $\mathrm{CO}_{2}$. J Geophys Res 114:G01013.

Noy-Meir I. 1973. Desert ecosystems, environments and producers. Ann Rev Ecol Syst 4:25-51.

Ode DJ, Tieszen LL, Lerman JC. 1980. The seasonal contribution of $\mathrm{C} 3$ and $\mathrm{C} 4$ plant species to primary production in a mixed prairie. Ecology 61:1304-11.

Park R, Epstein S. 1961. Metabolic fractionation of ${ }^{13} \mathrm{C}$ and ${ }^{12} \mathrm{C}$ in plants. Plant Physiol 36:133-8.

Pryor WA. 1973. Permeability-porosity patterns and variations in some Holocene sand bodies. Am Assoc Pet Geol Bull 57:162-89.
Raich JW, Schlesinger WH. 1992. The global carbon dioxide flux in soil respiration and its relationship to vegetation and climate. Tellus 44B:81-99.

Sandford AR, Mott RP, Shuleski PJ, Rinehart EJ, Caravella FJ, Ward RM, Wallace TC. 1977. Geophyscial evidence for a magma body in the vicinity of Socorro, New Mexico. In: Heacock JG, Ed. The earth's crust: its nature and physical properties, Vol. 20. Washington, DC: American Geophysical Monograph. p 385-404.

Schwinning S, Sala OE. 2004. Hierarchy of responses to resource pulses in arid and semi-arid ecosystems. Oecologia 141:211-20.

Serna-Pérez A, Monger HC, Herrick JE, Murray L. 2006. Carbon dioxide emissions from exhumed petrocalcic horizons. Soil Sci Soc Am J 70:795-805.

Shen W, Jenerette GD, Hui D, Phillips RP, Ren H. 2008. Effects of changing precipitation regimes on dryland soil respiration and $\mathrm{C}$ pool dynamics at rainfall event, seasonal and interannual scales. J Geophys Res 113:G03024.

Steinmann K, Siegwolf RTW, Saurer M, Körner C. 2004. Carbon fluxes to the soil in a mature temperate forest assessed by ${ }^{13} \mathrm{C}$ isotope tracing. Oecologia 141:489-501.

Stursova M, Sinsabaugh RL. 2008. Stabilization of oxidative enzymes in desert soil may limit organic matter accumulation. Soil Biol Biochem 40:550-3.

Taylor JA, Lloyd J. 1992. Sources and sinks of atmospheric $\mathrm{CO}_{2}$. Aust J Bot 40:407-18.

Wynn JG, Bird IM, Wong VNL. 2005. Rayleigh distillation and the depth profile of ${ }^{12} \mathrm{C} /{ }^{13} \mathrm{C}$ ratios of soil organic carbon from soils of disparate texture in Iron Range National Park, Far North Queensland, Australia. Geochim Cosmochim Acta 69:1961-73.

Wynn JG, Harden JW, Fries TL. 2006. Stable carbon isotope depth profiles and soil organic carbon dynamics in the lower Mississippi Basin. Geoderma 131:89-109. 